Reprod. Nutr. Dévelop., 1985, 25 (1 B), 255-270.

\title{
Lipoprotein lipase and the uptake of lipids by adipose cells during development
}

A. CRYER

Department of Biochemistry, University College Cardiff, P.O. Box 78, Cardiff, CP1 IXL Wales U.K.

\section{Introduction.}

Because of its pivotal role in the metabolism of circulating lipids, lipoprotein lipase has been the subject of concerted investigation for many years. Although much of the information that has been forthcoming has been reviewed in the recent past (Cryer, 1981 ; Quinn et al., 1982 ; Hamosh and Hamosh, 1983 ; Cryer, 1983) it is only fair to say that the ontogenic aspects of the enzyme and its action have been less fully addressed. Before attempting to provide a partial redress of this relative neglect the main features of lipoprotein lipase action will be reviewed.

The occurrence, distribution and molecular aspects of tissue lipoprotein lipase activity.

Lipoprotein lipase is found, most importantly, in the adipose, muscle and lung tissues of a large range of mammalian and avian species (Cryer and Jones, 1979a ; Cryer, 1981; Hamosh and Hamosh, 1983) including man (Nilsson-Ehle, 1974 ; Harlan et al., 1967). The enzyme is abundant in lactating mammary gland (McBride and Korn, 1963 ; Zinder et al., 1974) and milk (Egelrud and Olivecrona, 1972) and it has also been detected in vascular tissue (DiCorleto and Zilversmit, 1975), corpus luteum (Shemesh et al., 1976) and placenta (Mallov and Alousi, 1965 ; Elphick and Hull, 1977 ; Rothwell and Elphick, 1982). Although absent from adult liver a salt-sensitive "lipoprotein lipase " activity has been reported to be present in tissue taken from late-gestational rat foetuses (Chajek et al., 1977 ; Llobera et al., 1979). Those organs and tissues from which lipoprotein lipase activity is absent are not able to utilize circulating lipoprotein triglyceride fatty acids. For example, it has been shown that the small intestine has no lipoprotein lipase activity and is unable to use triglyceride fatty acids as an energy source (Hulsmann et al., 1981).

Changes in tissue lipoprotein lipase activities occur in response to a variety of conditions (for review see Cryer, 1981 ; Hamosh and Hamosh, 1983 ; Quinn et al., 
1982) and alterations in total activity show an overall correlation with modifications in the rate of triglyceride fatty acid uptake by the tissues in question (see also Vernon and Clegg, 1984).

Because intact triglyceride-rich lipoproteins cannot pass directly out of the plasma into the tissues across the endothelium the assumption has been made that lipoprotein lipase must act at or near the luminal surface of the capillary endothelial cells. The accumulated evidence more than adequately supports this view (reviewed in Cryer, 1983) and the currently accepted visualization of the molecular relationships that occur at the endothelium is shown in figure 1.

Although the enzyme exerts its physiological function at the endothelium, lipoprotein lipase can be recovered for example from adipose tissue and hearts with isolated adipocytes (Rodbell, 1964 ; Cryer et al., 1975a) and isolated cardiac muscle cells (Bagby et al., 1977 ; Chohan and Cryer, 1978) respectively. It could be thought that the enzyme within tissue parenchymal cells was physiologically insignificant. The many arguments which suggest the opposite have been reviewed previously (Cryer, $1981 ; 1983$ ) and it is now clear that the parenchymal cells of tissues are the source of the enzyme which is present at the endothelium. It is clear also that endothelial cells do not have the ability to produce lipoprotein lipase (Howard, 1977) despite their clearly demonstrated ability to bind quantities

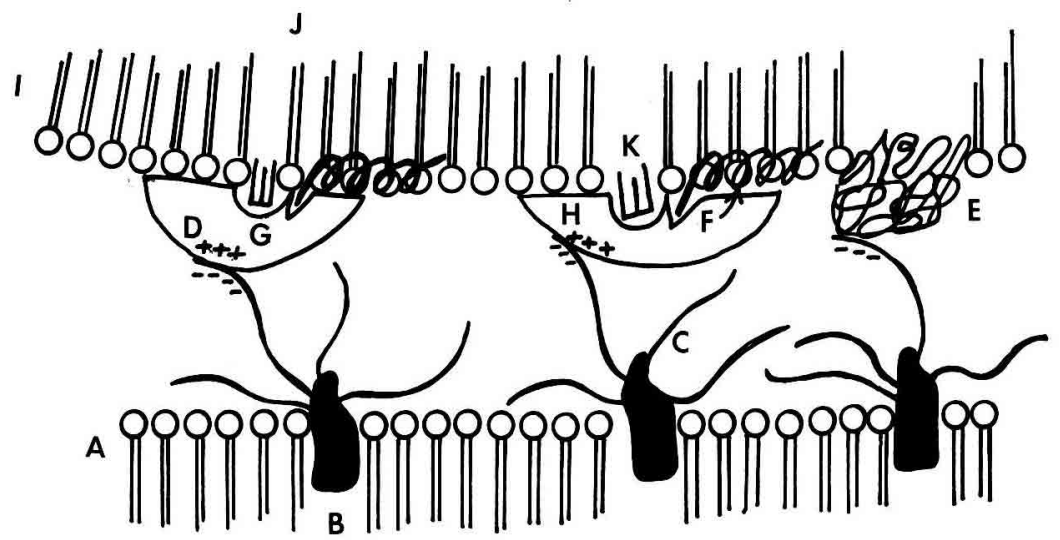

FIG. 1. - Proposed model of the interaction of endothelial cell-localized lipoprotein lipase and a triglyceride-rich lipoprotein partic/e.

The diagram shows the phospholipid monolayer of the outer leaflet of the endothelial cell plasma membrane (A) into which is anchored the hydrophobic portion of the heparan sulphate proteoglycan (B). The glycosaminoglycan chains of the heparan sulphate proteoglycan (C) exist as part of the extracellular endothelial glycocalyx and the strong negative charge present on these sulphated polymers provides the basis of the electrostatic interaction between the surface of the endothelium and the binding site on the lipoprotein lipase protein (D). In addition to the heparan sulphate glycosaminoglycan-binding site, the enzyme also binds apolipoprotein $C_{11}(F)$, an essential physiological activator of the enzyme which is present in the surface film of very low density lipoproteins and chylomicrons, via a specific binding site. Two other sites on the enzyme exist ; the active site (G), shown occupied by a triglyceride molecule $(\omega)$, and a lipid binding site $(H)$ which binds to the phospholipids present in the monolayer surface (I) of the lipoprotein particle which is characterized by its triglyceride-rich core (J). The lipoprotein may also interact with the endothelial glycosaminoglycan via apolipoprotein $E$ (E) (MacKinnon and Cryer, 1984).

The data in support of this model has been reviewed in Cryer (1981, 1983) and Williams et al. (1983). 
of the enzyme that are sufficient to account for observed rates of lipoprotein catabolism (Shimada et al., 1981 ; Cheng et al., 1981 ; Williams et al., 1983).

Changes in lipoprotein lipase activity occur in response to a range of nutritional, endocrinological and other physiological stimuli (Cryer, 1981 ; NilssonEhle et al., 1980) but, where it has been studied, the activity associated with the tissue parenchymal cells remained constant (Cunningham and Robinson, 1969 ; Chohan and Cryer, 1978) except where the conditions of, for example starvation, were particularly severe (Spencer et al., 1978). Thus, although the distribution of enzyme within the adipocyte for example may change under different physiological conditions (Verine et al., 1982 ; Al-Jafari, A. and Cryer, A. unpublished), the major change under such circumstances is in the proportion of total tissue activity which is outside parenchymal cells at the endothelial surface, where it is functional in lipoprotein triglyceride hydrolysis (Cryer, 1981).

\section{Control of the synthesis, secretion and movement of lipoprotein lipase in the tissues.}

Despite the attention the problems have attracted it is still the case that only a partial exposition can be given with regard to (i) the regulation of lipoprotein lipase synthesis within parenchymal cells (ii) the mechanism of its egress from cells and (iii) the means whereby it is transported to the endothelial site of its action. What is clear however is that the overall process of modulation within tissues is responsive to a variety of hormones (Cryer, 1981; Hamosh and Hamosh, 1983). Briefly, elevations in insulin concentrations lead to a rise in enzyme activity and polysomal activity (Cryer et al., 1976 ; Vydelingum et al., 1983 ) in adipose tissue where diurnal changes in lipoprotein lipase activity also relate to changes in plasma insulin levels (Pykalisto et al., 1975 ; Reichl, 1972). In general, those effectors that stimulate the (hormone-sensitive) triglyceride lipase of adipose tissue (e.g. Khoo et al., 1973) produce a reversal in otherwise elevated levels of lipoprotein lipase activity in adipose tissue. Thus insulin-stimulated increases in adipose tissue lipoprotein lipase activities are inhibited in the presence of catecholamines, adrenocorticotrophin, glucagon, thyroid stimulating hormone, dibutyryl cyclic-AMP, caffeine and theophylline (see Cryer, 1981 for review). Oestrogens also appear to depress lipoprotein lipase activities in adipose tissue (Hamosh and Hamosh, 1975a ; Wilson et al., 1976). Glucocorticoids enhance the insulin effects (Ashby and Robinson, 1980) and have an independent stimulatory effect on adipose tissue lipoprotein lipase activity (de Gasquet et al., 1975) probably via a specific effect on specific-enzyme synthesis (Ashby and Robinson, 1980).

The hormonal regulation of lipoprotein lipase in tissues other than adipose tissue is less well characterized. In the case of cardiac muscle, insulin has no effect (Robinson, 1970) whereas of the hormones suggested to stimulate total activity, glucagon (Borenstajn et al., 1973 ; de Gasquet et al., 1975 ; Kotlar and Borenstajn, 1977) catecholamines, thyroid hormones and corticosteroids (Alousi and Mallov, 1964 ; Torsti, 1965 ; Rodomski and Orme, 1971) are mentioned most 
often. Some studies also suggest that, additionally, norepinephrine (Hulsmann and Stam, 1978) and glucagon (Jansen et al., 1980 ; Simpson, 1979) bring about an increase in the proportion of total tissue activity that is involved in functional triglyceride hydrolysis. Furthermore, studies with mature isolated cardiocytes have revealed that both enzyme synthesis and secretion may be effected independently by glucocorticoids (Chohan and Cryer, 1980 ; Cryer et al., 1981, 1984a) in vitro.

At the molecular level the steps involved in the control of adipose tissue lipoprotein lipase have been suggested (Cryer, 1981 ; Hamosh and Hamosh, 1983) to be : - Firstly, glucocorticoid-stimulated enhancement of lipoprotein lipaseRNA synthesis and together with the more general effect of insulin on the activity of fat cell ribosomes and protein synthesis this brings about proenzyme synthesis. Completion of the proenzyme occurs by glycosylation, which permits the putative secretion of the mature enzyme from the cell (Cryer et al., 1981). The successful release of the enzyme from its intracellular site of synthesis in the endoplasmic reticulum (Vanhove et al., 1978 ; Chohan and Cryer, 1979) requires microtubular activity (Chajek et al., 1975 ; Cryer et al., 1975b) and it is probably at this stage, when the mature enzyme is ready for secretion, that the catecholamine-induced loss of activity comes about, possibly through an increased rate of specific protein degradation (Ashby et al., 1978). Recently it has become apparent that true release of the enzyme from the fat cell may not be necessary for its transport to the endothelium and that in common with a proposal related to the movement of lipolytic products (Scow et al., 1976 ; Smith and Scow, 1979) the enzyme may move in the proposed membranes continuum which may link fat cell, pericyte and endothelium (Blanchette-Mackie and Scow, 1981a, 1981b). In support of this has been the observation that a large proportion of the enzyme activity of isolated cells is associated with the adipocyte plasma membrane fraction following subcellular fractionation (Al-Jafari, A. and Cryer, A. unpublished observations) and that although total cell activity remains unchanged after fasting, both the proportion of immunodetectable enzyme (Cryer, A. and Al-Jafari, A. unpublished observations) and enzyme activity (Verine et al., 1982) at the plasma membrane is much higher in cells prepared from fed compared with those prepared from starved rats.

The activity of lipoprotein lipase in skeletal muscle responds to physiological change, with only a few exceptions (Linder et al., 1976), in a way similar to that of the heart. For example the activity rises in response to fasting (Cryer et al., 1976; Tan et al., 1977) and cold exposure (Begin-Heick and Heick, 1977). Lipoprotein lipase in the lung increases following the administration of glucocorticoids but does not appear to be responsive to changes in the concentration of insulin (Hamosh and Hamosh, 1975b ; Hamosh et al., 1976).

\section{The ontogeny of tissue lipoprotein lipase activity.}

The major part of the work that has been reported has been carried out with the developing rat. Although most of the information discussed here relates to this species an attempt to compare the events in other species has been made. 
It is clear that in general the main supply of metabolic energy that is available to a developing animal changes suddenly at birth. The change from primarily carbohydrate and fatty acid provision for the fetus to primarily milk triglyceride in the newborn requires well developed mechanisms for lipid transport and utilization to ensure the normal development of the newborn. For the rat during the neonatal period $70 \%$ of all its metabolic energy is derived from milk lipids (Rokos et al., 1963). Of these milk lipids $97 \%$ are triglycerides, $65 \%$ of which contain long rather than medium chain fatty acids (Fernando-Warnakulasuriya et al., 1981). Thus, in that the medium chain fatty acids find their preferential utilization by the liver (e.g. Ferré et al., 1981), the long-chain fatty acids contained in triglycerides will be directed towards the extrahepatic tissues. Thus by controlling the supply of longchain fatty acids at the tissue level, lipoprotein lipase must be assumed to have an important function in the growth and maturation of individual organs.

The activity of cardiac muscle lipoprotein lipase is very low in the fetus (Chajek et al., 1977 ; Cryer and Jones, 1978a ; Planche et al., 1980) but rises to adult levels during suckling. This pattern reflects the overall cellular development of the heart (Schriebler and Wolff, 1966) and the progressive increase in long chain fatty acid oxidation by the heart over this period. It has been suggested for example that « association of the increase of capacity for palmitate oxidation with the postnatal emergence of lipoprotein lipase in heart muscle is plausible " (Glatz and Veerkamp, 1982) and that increased oxidative capacity is related to cardiac mitochondrial maturation (Barrie and Harris, 1977).

In the case of the rat lung, lipoprotein lipase activity has been detected up to 5 days before birth and increases substantially during the last few hours in utero and during the first day of extrauterine life (Hamosh et al., 1978 ; Cryer and Jones, 1978a ; Hietanen and Hartiala, 1979 ; Planche et al., 1980). The enzyme activity is elevated therefore during the period of lung development when rapid rates of pulmonary surfactant synthesis occur (Farrell and Hamosh, 1978) and it has been suggested that the increased perinatal pulmonary lipoprotein lipase activity may provide a source of diglyceride for the dipalmitylphosphatidylcholine production necessary for pulmonary surfactant formation (Cryer and Jones, 1978a ; Weinhold et al., 1980). It is also tempting to speculate that a relationship exists between the precocious increase in lipoprotein lipase activity produced by the administration of dexamethasone in utero (Mostello et al., 1981) and the morphological and functional changes induced in the lung by the same stimulus. These changes include the enhanced differentiation of type II pneumocytes, enhanced pulmonary function and an increase in the levels of total and disaturated phosphatidylcholine in the fetal lungs and alveolar spaces of a number of species (see Possmayer, 1982 for review).

The low activity of lipoprotein lipase present in fetal skeletal muscle emerges to a relatively high neonatal level within hours of birth (Cryer and Jones, 1978a ; Planche et al., 1980). The activity then reaches a peak in the early to mid-suckling period. The activity declines during late suckling and the weaned animal then has levels of activity similar to those found in tissue from adults. As was the case in heart this increase in skeletal muscle lipoprotein lipase activity may provide the 
fuel for the increase in the capacity for fatty acid oxidation that occurs in skeletal muscle during the neonatal period (Glatz and Veerkamp, 1982). The lipoprotein lipase activity of the skeletal muscle mass has been adduced to have a particular significance in the suckling animal. Thus Planche et al. (1980) concluded that in 60-day-old rats, more than $50 \%$ whole-body lipoprotein lipase activity was present in adipose tissue in the fed state and that this proportion of the total was present in cardiac and skeletal muscle in the starved state. This overall pattern being similar to that seen in adult rats (Tan et al., 1977) or mice (Rath et al., 1974). During the suckling period however lipoprotein lipase present in the muscles amounted to between 63 and $85 \%$ of total activity in both fed and fasted pups.

Thus in the suckling pup it would appear that muscle lipoprotein lipase activity is particularly significant and is largely responsible for the hydrolysis of chylomicron triglyceride. This situation also pertains in the case of adult rats fed a high-fat diet (De Gasquet et al., 1977 ; Weissemburg-Delorme and Harris, 1975). The high capacity for triglyceride hydrolysis by the muscle mass of suckling rats may contribute significantly to the high free fatty acid concentrations present in the plasma at this stage of development (Planche et al., 1980) because as illustrated by Scow and colleagues up to $40 \%$ of triglyceride fatty acid liberated by lipoprotein lipase action at the endothelium may enter the plasma rather than the tissues and thus become available for utilization elsewhere (Scow et al., 1976).

\section{The ontogeny of lipoprotein lipase in adipose tissues.}

Brown adipose tissue. - The importance of brown adipose tissue as a thermogenic organ, particularly in the early part of life has been demonstrated clearly and reviewed fully (Cannon and Nedergaard, 1982; Nedergaard and Lindberg, 1982). The fuel for thermogenesis in the tissue is free fatty acid derived from stored triglyceride. However since it has been suggested that « plasma free fatty acids do not serve as a substrate for thermogenesis " (Schenk et al., 1975) and because the rate of fatty acid synthesis in brown adipose tissue is low in suckling mice (Trayhurn, 1981) and that the latter process only becomes significant following weaning in the rat (Pillay and Bailey, 1982) it is clear that plasma lipids derived from mothers milk must be the source of thermogenic fuel during suckling. Consistent with these observations is the high level of lipoprotein lipase activity present in the brown adipose tissue of fetal and suckling rats (Cryer and Jones, 1978a). In the present author's experience the activity present in the brown adipose tissue of suckling rats is one of the highest activities recorded $(500 \mu \mathrm{MoleFFA} / \mathrm{h} / \mathrm{g}$ fresh wt) being comparable to that found in lactating mammary gland. The activity in brown adipose tissue exhibits two peaks of activity at 2 and 12 days of age with a fall to relatively low levels by weaning. The high total and heparin-releasable (Hemon et al., 1975) lipoprotein lipase activity present in the tissue during suckling may provide a mechanism therefore, whereby a preferential utilization of circulating triglyceride fatty acid either as oxidizable fuel for thermogenesis or as a source of the intracellular triglyceride 
stored by the tissue could be envisaged. The decline in brown adipose tissue lipoprotein lipase activity at mid-suckling may be related to the known response of the enzyme in the tissue to cold-exposure. Thus the increases in tissue enzyme activity in suckling (Hemon et al., 1975) and in early weaned animals (Cryer, A. and Jones, H. M. unpublished) and which occur in response to cold (Rodomski and Orme, 1971 ; Guerrier and Pellet, 1979) could be related to behavioural changes (e.g. exploratory activity) occurring at mid-suckling (Henning, 1981) which require an increase in the provision of thermogenic fuel. The regulation of these changes however remains to be explained fully.

White adipose tissue. - The changes that occur in the total activity of lipoprotein lipase in various white adipose tissues in a variety of species during development has received considerable attention (see Cryer, 1982 for review) but, because in many situations the reports have been less than completely consistent, it is difficult to make comparisons. However an attempt will be made to review the data and relate it to the accretion of lipid by white adipose tissue.

In many species, the fatty acids derived from plasma lipoprotein triacylglycerol are the predominant source of fatty-acyl components present in the stored lipid of adipocytes (Hollenberg, 1966) with fatty acid synthesis de novo generally making a relatively minor contribution (Roncari and Van, 1978). Despite this qualification, white adipose tissue can have an important role in the synthesis of long-chain fatty acids in some species. Pigs (O'Hea and Leveille, 1969), sheep (Hanson and Ballard, 1967 ; Ingle et al., 1972) and cattle (Hanson and Ballard, 1967) for example, synthesize a majority of their fatty acids in adipose tissue. This situation is by contrast with that in the mouse (Jansen et al., 1966) and rat (Jansen et al., 1966 ; Leveille, 1976) where both liver and white adipose tissue-are involved and in further contrast to the chick (Leveille et al., 1968), pigeon (Goodridge and Ball, 1976) and human (Shrago et al., 1969) where fatty acid synthesis is an almost exclusively hepatic function with white adipose tissue acting merely as a storage site for preformed fatty acids. The subsequent consideration might best be divided into a consideration of the situation in experimental (laboratory) animals and to animals of economic importance.

It may be proposed then, for the laboratory animals that are most commonly studied, that by analogy with other systems, changes in the activity of the lipoproteins lipase activity in white adipose tissue during development will reflect the extent to which plasma triacylglycerol is hydrolyzed and the free fatty acid products are taken up by the adipocytes. Although as intimated previously, the total activity of lipoprotein lipase may not relate directly to triglyceride fatty acid uptake capacity into adipose cells under all conditions and heparin-induced release rates for the enzyme in vivo have been suggested as an alternative (Das et al., 1982), under most conditions, where useful comparisons can be made, the correlation between the two variables holds (Cryer et al., 1976).

As might be expected, the low level of circulating triglyceride concentrations found in the fetus are elevated up to four times the normal adult level throughout suckling in the rat (Cryer and Jones, 1978b) and even at the earliest postnatal stages this plasma lipoprotein triglyceride can act as a substrate for lipoprotein lipase since adequate amounts of functional apolipoprotein $C_{\|}$are also present 
(Cryer and Jones, 1978c). In the rat the pattern of change in adipose tissue lipoprotein lipase activity is remarkably similar when anatomically-distinct depots are compared. In general, the small amounts of immature triglyceride-poor white adipose tissue present at birth contains significant levels of lipoprotein lipase activity (Cryer and Jones, 1978a ; Pequignot-Planche et al., 1977). During the first six hours of life however, during which time no accumulation of triglyceride occurs in the tissue, the enzyme activity declines somewhat in a response that is probably related to a fall in plasma insulin levels within the first six hours of birth (Blasquez et al., 1974 ; 1975). During the $6-24 \mathrm{~h}$ period of postnatal life both the lipoprotein lipase activity and triglyceride content of the tissue increases substantially. This increase is sustained progressively over the first 10 days of life such that levels of activity 2-4 times greater than adult levels are achieved by midsuckling. This pattern was observed whether the activity was expressed as units/g of tissues or units/whole depot. Following the 10th day of life the activity in all the depots fell progressively over the remainder of the suckling period reaching minimal levels on day 20 . Thereafter the activities rose again and remained relatively high for the period up to about 8-10 weeks of age after which they declined to the relatively constant adult level by the 20th week of life. It is clear that in the first 10 days of life the relatively small increases that occur in adipose tissue mass relative to body weight changes occur substantially as a result of active cellular hyperplasia together with a modest increase in the size of recognizable fat cells (Cryer and Jones, 1979b; 1980). Thus, although the changes in activity per cell (recognizable adipocyte) correlate with the rate of lipid accretion by the tissue over this period it is clear that a proportion of the total tissue enzymes activity increase is dependent upon the emergence of lipoprotein lipase activity in predetermined, but hitherto undifferentiated adipocyte present in the tissue (Ailhaud, 1982 ; Cryer, 1984 see also Hietanen and Greenwood, 1977). The decline in adipose tissue lipoprotein lipase activities during the second half of suckling are less easily related to the aspects of cellularity and lipid accretion just discussed. In the first case the total lipid content of most depots continue to increase over this period (Cryer and Jones, 1979b) and pad growth continues (Cryer and Jones, 1979b; Planche et al., 1980) as does adipocyte cell size although adipocyte numbers do not alter substantially (Cryer and Jones, 1979b). A number of possible explanations for this may be advanced, the high lipogenic capacity of late suckling adipose tissue together with a low rate of intracellular triglyceride turnover in adipocytes coupled with the high levels of serum free fatty acids generated by the high capacity of the muscle lipoprotein lipase system at this time may all combine to maintain the rate of storage of caloric excess in adipose tissue while the low adipose and high muscular lipoprotein lipase activity serve to direct the high level of dietary-derived triglyceride to tissues where high rates of oxidative metabolism must be fueled by lipid (see Cryer and Jones, 1978 ; Planche et al., 1980). Following weaning in the rat average adipocyte size increases substantially in a fashion which is related to the activity of lipoprotein lipase expressed on a per cell basis (Hietanen and Greenwood, 1977) thus « lipidfilling " of differentiated adipocytes again seems related to the activity of this enzyme. 
During growth and dietary manipulation in ruminants, lipoprotein lipase activity in different adipose depots seems to behave differently. Although much less information is available the following observations may be made, and the area is very active currently because of the economic implications to the food industry.

As noted by Hood (1982) in early postnatal development, growth of adipose tissue is due to both cellular hypertrophy and hyperplasia. Adipocyte hypertrophy is the major mechanism in the fattening of ruminants grown to market weight, although evidence is accumulating that preadipose cells can proliferate postnatally, even in mature animals (see for example of this possibility in the bovine Plaas and Cryer, 1980 ; Cryer et al., 1984b). The relation of adipocyte hypertrophy to lipoprotein lipase activity in ruminants has received some attention. For example Merkel et al. (1976) found that in developing sheep the deposition of exogenous fat in the different adipose depots correlated with the changes in lipoprotein lipase activity that occurred. Furthermore the relationships between feed-type, genetic background and depot site on lipid accretion and lipoprotein lipase activity in the bovine has been reviewed by Hood (1982). In pigs the available data suggests that lipoprotein lipase activity in adipose tissues is relatively high at birth and increases dramatically during the early neonatal (suckling) period (Steffen et al., 1978) when lipogenesis de novo is low in the tissue but lipid accumulation is rapid. Again the relationship between lipoprotein lipase activity and lipid accumulation is close in this species also and is maintained throughout the important period of fattening in these animals too.

\section{The lipoprotein lipase activity of differentiating adipocyte precursors and their capacity for lipid storage.}

Although lipoprotein lipase exercises its physiological function at the lumenal surface of the vascular endothelium in adipose tissue the enzyme is synthesized by the adipocyte (Cryer, 1981, 1983 for reviews) and because of this and other reasons the presence of the enzyme has been used extensively as a marker of the adipocyte phenotype for studies of precursor cells in vitro. The importance of lipoprotein lipase activity to the accretion of lipid for storage by these differentiating cells is illustrated by the observation that despite the appreciable rates of fatty acid synthesis that occur in murine white adipose tissues (Jansen et al., 1966) neither the onset, rate nor extent of the adipose differentiation of mouse embryo $3 T 3-L_{1}$ preadipocytes was affected by a complete inhibition of fatty acid synthesis de novo (Coleman et al., 1978). Thus maximal lipid accumulation rates could be observed when lipoprotein lipase action was the only source of fatty acid moieties for storage. The activity of lipoprotein lipase in precursor cells isolated from the adipose tissue of mature individuals of a number of species (Cryer, 1984 for review) has been studied extensively during differentiation of these cells in culture. The enzyme emergence was characteristic of the differentiation of these cell types and it is of relevance to the previous discussions that the presence of insulin was not necessary for the increases in enzyme activity that are observed.

Reproduction Nutrition Développement, $\mathrm{n}^{\circ} 1 \mathrm{~B}-1985$. -8 . 
It is clear also that lipid accretion in such systems is highly dependent on the action of lipoprotein lipase in that supplementation of the medium in which the cells are grown with lipoprotein triglyceride or an appropriate triglyceride emulsion causes the cells to accumulate much more lipid (Björntorp et al., 1980 ; Van and Roncari, 1978 ; Cryer A. and Cryer J. unpublished) and that this does not depend on release of enzyme into the medium but again suggests the potentially functional capacity of cell surface bound enzyme in the hydrolysis of exogenous substrate.

Thus such a system together with continued studies in vivo, offers, together with immunodetection of the cellular enzyme (Vannier et al., 1982 ; Al-Jafari and Cryer, 1984 and unpublished), the opportunity to study the hormonal and other factors which may control the development of lipoprotein lipase and ensure its controlled action throughout life.

$10^{e}$ Réunion du groupe Développement I.N.R.A., Rennes, 9-10 mai 1984.

Acknowledgements. - The financial assistance of the Medical Research Council, The Agricultural and Food Research Council and the Science and Engineering Research Council for parts of this work are gratefully acknowledged. The help of Heather Jones, Jennifer Cryer, Abdulaziz Al-Jafari and other members of my research group, past and present, is also much appreciated.

Résumé. La lipoprotéine lipase et le captage des lipides par les cellules adipeuses au cours du déve/oppement.

Le dépôt des triglycérides stockés dans les adipocytes peut faire intervenir deux processus, à savoir 1) l'accrétion des lipides provenant directement des lipoprotéines plasmatiques, 2) la biosynthèse in situ.

Le principal facteur qui régule le captage des triglycérides des lipoprotéines plasmatiques est la lipoprotéine lipase. Cette enzyme, qui provient de l'adipocyte, agit à la surface des capillaires sur les triglycérides des chylomicrons et des VLDL ; elle conduit à la libération d'acides gras et de monoglycérides qui traversent les membranes des cellules endothéliales, des péricytes et des adipocytes avant d'être réestérifiés sous forme de triglycérides dans le réticulum endoplasmique lisse de l'adipocyte.

Quoiqu'il existe d'importantes exceptions, les triglycérides des lipoprotéines plasmatiques constituent dans la plupart des espèces la source principale des lipides de réserve et la néosynthèse $d^{\prime}$ acides gras dans les tissus adipeux ne joue généralement qu'un rôle mineur.

Le présent rapport a pour objet de passer en revue les points essentiels dans les domaines suivants : - mécanismes moléculaires de l'action de la lipoprotéine lipase sur les lipoprotéines riches en triglycérides ; - la distribution de l'enzyme entre les cellules des tissus (par exemple les adipocytes) et ses localisations extratissulaires ; - les modifications de l'activité de l'enzyme induites par des facteurs nutritionnels ; - ce que l'on connaît des réactions moléculaires qui contrôlent la synthèse et les mouvements de l'enzyme.

L'évolution de l'activité de la lipoprotéine lipase dans les tissus au cours du développement sera examinée en considérant le rôle que tient cette évolution dans la répartition des lipides circulants entre les différents tissus.

L'évolution de l'activité de la lipoprotéine lipase dans les tissus adipeux sera considérée au regard de la croissance des tissus adipeux et des taux d'hormones circulantes.

La relation entre l'évolution de l'activité de la lipoprotéine lipase et les mécanismes fondamentaux de la croissance des tissus adipeux par hypertrophie et hyperplasie sera considérée conjointement à l'utilisation de cultures de cellules précurseurs d'adipocytes comme modèle pour des études ultérieures. 


\section{Références}

AlLHAUD G., 1982. Adipose cell differentiation in culture. Mol. cell. Biochem., 49, 17-31.

AL-JAFARI A. A., CRYER A., 1984. The enzyme inhibitory activity of chicken anti-rat lipoprotein lipase serum. Biochem. Soc. Trans. (in the press).

ALOUSI A. A., MALLOV S., 1964. Effects of hyperthyroidism, epinephrine and diet on heart lipoprotein lipase activity. Am. J. Physiol., 206, 603-609.

ASHBY P., ROBINSON D. S., 1980. Effect of insulin, glucocorticoids and adrenaline on the activity of rat adipose tissue lipoprotein lipase. Biochem. J., 188, 185-192.

ASHBY P., BENNETT D. P., SPENCER I. M., ROBINSON D. S., 1978. Post-translational regulation of lipoprotein lipase activity in adipose tissue. Biochem. J., 176, 865-872.

BAGBY G., LIU M.-S., SPITZER J. A., 1977. Lipoprotein lipase activity in rat heart myocytes. Life Sci., 21, 550-555.

BARRIE S., HARRIS P., 1977. Myocardial enzyme activities in guinea pigs during development. Am. J. Physiol, 233, 4707-4710.

BEGIN-HEICK N., HEICK H. M. C., 1977. Increased lipoprotein lipase activity of skeletal muscle in cold acclimated rats. Can. J. Biochem., 55, 1241-1243.

BJÖRNTORP P., KARLSSON M., PETTERSSON P., SYPNIEWSKA G., 1980. Differentiation and function of rat adipocyte precursor cells in primary culture. J. Lipid Res., 19, 714-723.

BLANCHETTE-MACKIE E. J., SCOW R. O., 1981a. Membrane continuites within cells and intercellular contacts in white adipose tissue of young rats. J. U/trastr. Res., 77, 277-294.

BLANCHETTE-MACKIE E. J., SCOW R. O., 1981b. Lipolysis and lamellar structures in white adipose tissue of young rats : lipid movement in membranes. J. U/trastr. Res., 77, 295-318.

BLASQUEZ E., SUGASE T., BLASQUEZ M., FOA P. P., 1974. Neonatal changes in rat liver cyclic AMP and of serum glucose, free fatty acids, insulin pancreatic and total glucagon in man in the rat. J. Lab. clin. Med., 83, 957-967.

BLASQUEZ E., LIPSHAW L. A., BLASQUEZ M., FOA P. P., 1975. The synthesis and release of insulin in fetal, nursing and young adult rats: Studies in vivo and in vitro. Pediatr. Res., 9, 17-25.

BORENSTAJN J., KEIG P., RUBENSTEIN A. H., 1973. The role of glucagon in the regulation of myocardial lipoprotein lipase activity. Biochem. biophys. Res. Commun., 53, 603-608.

CANNON B., NEDERGAARD J., 1982. The function and properties of brown adipose tissue in the newborn, 697-730. In C. T. JONES, Biochemical development of the fetus and neonate, Elsevier biomed. Press, Amsterdam.

CHAJEK T., STEIN O., STEIN Y., 1975. Interference with the transport of heparin-releasable lipoprotein lipase in the perfused rat heart by colchicine and vinblastine. Biochim. biophys. Acta, 388, 260-267.

CHAJEK T., STEIN O., STEIN Y., 1977. Pre and post-natal development of lipoprotein lipase and hepatic triglyceride hydrolase activity in rat tissues. Atherosc/erosis, 26, 549-561.

CHENG C.-F., COSTA G. M., BENSADOUN A., ROSENBERG R. D., 1981. Binding of lipoprotein lipase to endothelial cells in culture. $J$. biol. Chem., 256, 12893-12898.

CHOHAN P., CRYER A., 1978. The lipoprotein lipase (clearing factor lipase) activity of cells isolated from rat cardiac muscle. Biochem. J., 174, 663-666.

CHOHAN P., CRYER A., 1979. Lipoprotein lipase activity of rat cardiac muscle. The intracellular distribution of the enzyme between fractions prepared from cardiac muscle and cells isolated from the hearts of fed and starved animals. Biochem. J., 181, 83-93.

CHOHAN P., CRYER A., 1980. Lipoprotein lipase activity of rat cardiac muscle. Changes in the enzyme activity during incubations of isolated cardiac muscle cells in vitro. Biochem. J., 186, 873-879.

COLEMAN R. A., REED B. C., MACKALL J. C., STUDENT A. K., LANE D. M., BELL R. M., 1978. Selective changes in microsomal enzymes of triacylglycerol, phosphatidylcholine and phosphatidylethanolamine biosynthesis during the differentiation of $3 T 3-L_{1}$ preadipocytes. $J$. biol. Chem., 253, 7256-7261.

CRYER A., 1981. Tissue lipoprotein lipase activity and its action in lipoprotein metabolism. Int. J. Biochem., 13, 525-541. 
CRYER A., 1982. The growth and metabolism of developing white adipose tissue, 731-757. In C. T. JONES, Biochemical development of the fetus and neonate, Elsevier biomed. Press, Amsterdam.

CRYER A., 1983. Lipoprotein lipase-endothelial interactions, 245-274. In CRYER A., Biochemical interactions at the endothelium, Elsevier Sci. Publ., Amsterdam.

CRYER A., 1984. Biochemical markers of adipocyte precursor differentiation. In CRYER A., VAN R. L. R., New perspectives in adipose tissue, structure, function and development. Butterworths, London (in the press).

CRYER A., JONES H. M., 1978a. Developmental changes in the activity of lipoprotein lipase (clearing factor lipase) in rat lung, cardiac muscle, skeletal muscle and brown adipose tissue. Biochem. J., 174, 447-451.

CRYER A., JONES H. M., 1978b. Changes in the lipoprotein lipase (Clearing factor lipase) activity of white adipose tissue during development of the rat. Biochem. J., 172, 319-325.

CRYER A., JONES H. M., 1978c. Parallel changes between lipoprotein lipase activating capacity and lipid concentrations in the serum of rats and ferrets during development and dietary manipulation. Clin. Sci. mol. Med., 55, 121-123.

CRYER A., JONES H. M., 1979a. The distribution of lipoprotein lipase (Clearing factor lipase) activity in the adiposal, muscular and lung tissues of 10 animal species. Comp. Biochem. Physiol., 63B, 501-505.

CRYER A., JONES H. M., 1979b. The Early development of white adipose tissue. Effects of litter size on the lipoprotein lipase activity of four adipose-tissue depots serum immunoreactive insulin and tissue cellularity during the first four weeks of life in the rat. Biochem. J., 178, 711-724.

CRYER A., JONES H. M., 1980. The development of white adipose tissue. Effect of litter size on the lipoprotein lipase activity of four adipose-tissue depots, serum immunoreactive insulin and tissue cellularity during the first year of life in male and female rats. Biochem. J., 186, 805815.

CRYER A., DAVIES P., WILLIAMS E. R., ROBINSON D. S., 1975a. The Clearing-factor lipase activity of isolated fat cells. Biochem. J., 146, 481-488.

CRYER A., MCDONALD A., WILLIAMS E. R., ROBINSON D. S., 1975b. Colchicine inhibition of the heparin-stimulated release of clearing factor lipase from isolated fat cells. Biochem. J., $152,717-720$.

CRYER A., RILEY S. E., WILLIAMS E. R., ROBINSON D. S., 1976. Effects of nutritional status on rat adipose tissue, muscle and post heparin plasma clearing-factor lipase activities : their relationship to triglyceride fatty acid uptake by fat cells and to plasma insulin concentrations. Clin. Sci. mol. Med., 50, 213-221.

CRYER A., CHOHAN P., SMITH J. J., 1981. Effectors of lipoprotein lipase secretion from isolated cardiac muscle cells incubated in vitro. Life Sci., 29, 923-929.

CRYER A., WUSTEMAN F. S., CASEY J. J., 1984a. Glycosaminoglycan : cell interactions ; their role in lipoprotein lipase secretion from isolated cardiac muscle cells. Cell. Biochem. Function, 2, 53-56.

CRYER A., GRAY B. R., WOODHEAD J. S., 1984b. Studies on the characterization of bovine adipocyte precursor cells and their differentiation in vitro, using an indirect-labelled-secondantibody cellular immunoassay. J. develop. Physiol., 6, 159-176.

CUNNINGHAM V. J., ROBINSON D. S., 1969. Clearing factor lipase in adipose tissue. Distinctions of different states of the enzyme and the possible role of the fat cell in the maintenance of tissue activity. Biochem. J., 112, 203-209.

DAS J. B., JOSHI I. D., PHILIPPART A. I., 1982. The storage and synthetic pools of heparinreleasable lipoprotein lipase and hepatic triacylglycerol lipase in the growing puppy. Biochem. J., 206, 663-666.

DE GASOUET P., PEQUignOT-PLANCHE E., TONNU N. T., DIABY F. A., 1975. Effect of glucocorticoids on lipoprotein lipase activity in rat heart and adipose tissue. Horm. Metab. Res., 7, 152-157.

DE GASOUet P., GRIGlio S., PEQUignot-PLANChe E., MALEWIAK M. I., 1977. Diurnal changes in plasma and liver lipids and lipoprotein lipase activity in heart and adipose tissue in rats fed a high- and low-fat diet. $J$. Nutr., 107, 119-212. 
DiCORLETO P. E., ZILVERSMIT D. B., 1975. Lipoprotein lipase activity in bovine aorta. Proc. Soc. exp. Biol. Med., 148, 1101-1105.

EGELRUD T., OLIVECRONA R., 1972. The purification of a lipoprotein lipase from bovine skim milk. J. biol. Chem., 247, 6212-6217.

ELPHICK M. C., HULL D., 1977. Rabbit placental clearing factor lipase and transfer to the foetus of fatty acids derived from triglycerides injected into the mother. J. Physiol., 273, 475-487.

FARRELL P. M., HAMOSH M., 1978. The biochemistry of lung development. Clin. Perinatal, 5, 197-229.

FERNANDO-WARNAKULASURIYA G. J. P., STAGgERS J. E., FROST S. C., WELLS M. A., 1981. Studies on fat digestion, absorption and transport in the suckling rat. I. Fatty acid composition and concentrations of major lipid components. J. Lipid Res., 22, 668-672.

FERRÉ P., SATABIN P., MANOUBI L. El., CALLIKAN S., GIRARD J., 1981. Relationship between ketogenesis and gluconeogensis in isolated hepatocytes from newborn rats. Biochem. J., 200, 429-433.

GLATZ J. F. C., VEERKAMP J. H., 1982. Post-natal development of palmitate oxidation and mitochondrial enzyme activities in rat cardiac and skeletal muscle. Biochim. biophys. Acta, 711, 327-335.

GOODRIDGE A. G., BALL E. G., 1976. Lipogenesis in the pigeon in vivo studies. Am. J. Physiol., 213, 245-249.

GUERRIER D., PELLET H., 1979. Purification and characterization of lipoprotein lipase from rat brown fat. FEBS Letts., 106, 115-120.

HAMOSH M., HAMOSH P., 1975a. The effect of estrogen on the lipoprotein lipase activity of rat adipose tissue. J. clin. Invest., 55, 1132-1135.

HAMOSH M., HAMOSH P., 1975b. Lipoprotein lipase in rat lungs. The effect of fasting. Biochim. biophys. Acta, 380, 132-140.

HAMOSH M., HAMOSH P., 1983. Lipoprotein lipase : Its physiological and clinical significance. Molec. Aspects Med., 6, 199-289.

HAMOSH M., YEAGER H., SHECHTER Y., HAMOSH P., 1976. Lipoprotein lipase in rat lung. Effect of dexamethasone. Biochim. biophys. Acta, 431, 519-525.

HAMOSH M., SIMON M. R., CANTER H., HAMOSH P., 1978. Lipoprotein lipase activity and blood triglyceride levels in fetal and newborn rats. Pediatr. Res., 12, 1131-1136.

HANSON R. W., BALLARD J. F., 1967. The relative significance of acetate and glucose as precursors for lipid synthesis in liver and adipose tissue from ruminants. Biochem. J., 105, 529536.

HARLAN W. R., WINOSETT P. S., WASSERMAN A. J., 1967. Tissue lipoprotein lipase in normal individuals and in individuals with exogenous hypertriglyceridemia and the relationship of this enzyme to assimilation of fat. J. clin. Invest, 46, 239-247.

HEMON P., RICQUIER D., MORY G., 1975. The lipoprotein lipase activity of brown adipose tissue during early post-natal development of the normal and hypothyroid rat. Horm. Metab. Res., 7. $481-484$.

HENNING S. J., 1981. Postnatal development ; coordination of feeding, digestion and metabolism. Am. J. Physiol., 241, G199-214.

HIETANEN E., GREENWOOD M. R. C., 1977. A comparison of lipoprotein lipase activity and adipocyte differentiation in growing male rats. J. Lipid Res., 18, 480-490.

HIETANEN E., HARTIALA J., 1979. Development pattern of pulmonary lipoprotein lipase in growing rats. Biol. Neonate, 36, 85-91.

HOLLENBERG C. H., 1966. The origin and glyceride distribution of fatty acids in rat adipose tissues. J. clin. Invest., 45, 205-216.

HOOD R. L., 1982. Relationships among growth adipose cell size, and lipid metabolism in ruminant adipose tissue. Fed. Proc. Fed. am. Soc. exp. Biol., 41, 2555-2561.

HOWARD B. V., 1977. Uptake of very low density lipoprotein triglyceride by bovine aortic endothelial cells in culture. J. Lipid Res., 18, 561-571.

HULSMANN W. C., STAM H., 1978. Intracellular origin of hormone-sensitive lipolysis in the rat. Biochem. biophys. Res., Commun., 82, 53-59. 
HULSMANN W. C., BREEMAN W. A. P., STAM H., KORT W. J., 1981. Comparative study of chylomicron and fatty acid utilization in small intestine and heart. Biochim. Biophys. Acta, 663, 373-379.

INGLE D. L., BAUMAN D. E., GARRIGUS U. S., 1972. Lipogenesis in the ruminant in vitro study of tissue sites, Carbon source and reducing equivalent generation for fatty acid synthesis. $J$. Nutr., 102, 609-616.

JANSEN G. R., ZANETTI M. E., HUTCHISON C. F., 1966. Studies on lipogenesis in vivo : Effects of starvation and refeeding and studies on cholesterol of synthesis. Biochem. J., 99, 333-340.

JANSEN H., STAM H., KALKMAN C., HULSMANN W. C., 1980. On the dual location of lipoprotein lipase in rat heart, studies with a modified perfusion technique. Biochem. biophys. Res. Commun., 92, 411-416.

KHOO J. C., STEINBERG D., THOMPSON B., MAYER E., 1973. Hormonal regulation of adipocyte enzymes. The effects of epinephrine and insulin on the control of lipase, phosphorylase kinase, phosphorylase and glycogen synthase. J. biol. Chem., 248, 3823-3830.

KOTLAR T. J., BORENSTAJN J., 1977. Oscillatory changes in muscle lipoprotein lipase of fed and starved rats. Am. J. Physiol., 233, E316-E319.

LEVEILLE G. A., 1976. In vivo fatty acid synthesis in adipose tissue and liver of meal-fed rats. Proc. Soc. exp. Biol. Med., 125, 85-88.

LEVEILLE G. A., O'HEA E. K., CHAKRABARTY K., 1968. In vivo lipogenesis in the domestic chicken. Proc. Soc. exp. Biol. Med., 128, 398-401.

LINDER C., CHERNICK S. S., FLECK T. R., SCOW R. O., 1976. Lipoprotein lipase and uptake of chylomicron triglyceride by skeletal muscle of rats. Am. J. Physiol., 231, 860-864.

LLOBERA M., MONTES A., HERRERA E., 1979. Lipoprotein lipase activity in the liver of rat foetuses. Biochem. Biophys. Res. Commun., 91, 272-277.

MacKINNON N. O., CRYER A., 1984. A comparison of the composition and catabolism in vitro of porcine very low density lipoprotein subfractions prepared by gel filtration and heparin-affinity chromatography. Int. J. Biochem., 16, 213-218.

MALLOV S., ALOUSI A. A., 1965. Lipoprotein lipase activity of rat and human placenta. Proc. Soc. exp. Biol. Med., 119, 301-306.

McBRIDE O. W., KORN E. D., 1963. The lipoprotein lipase of mammary gland and the correlation of its activity to lactation. J. Lipid Res., 4, 17-20.

MERKEL R. A., SIDHU K. S., EMERY R. S., SPOONER M. E., ROMSOS D. R., PARR A. F., 1976. Cellularity lipoprotein lipase and glyceride synthesis in bovine adipose tissue. In Biology of fat in meat animals, Madison Univ. Wisconsin, North Central Reg. Res. Publ., No. 234, 234-269.

MOSTELLO D. J., HAMOSH M., HAMOSH P., 1981. Effect of dexamethasone on lipoprotein lipase activity of fetal rat lung. Biol. Neonate, 40, 121-128.

NEDERGAARD J., LINDBERG O., 1982. The brown fat cell. Int. Rev. Cytol., 74, 187-286.

NILSSON-EHLE P., 1974. Human lipoprotein lipase activity; comparison of assay methods. Clin. chim. Acta, 54, 283-291.

NILSSON-EHLE P., GARFINKEL A. S., SCHOTZ M. C., 1980. Lipolytic enzymes and plasma lipoprotein metabolism. Annu. Rev. Biochem., 49, 667-693.

O'HEA E. K., LEVEILLE G. A., 1969. Significance of adipose tissue and liver as sites of fatty acid synthesis in the pig. $J$. Nutr., 99, 338-344.

PEQUIGNOT-PLANCHE E., de GASOUET P., BOULANGE A., TONNU N. T., 1977. Lipoprotein lipase activity at the onset of development of white adipose tissue in newborn rats. Biochem. J., 162, 461-463.

PILLAY D., BAILEY E., 1982. Lipogenesis at the suckling-weaning transition in liver and brown adipose tissue of the rat. Biochim. biophys. Acta, 713, 663-669.

PLAAS H. A. K., CRYER A., 1980. The isolation and characterization of a proposed adipocyte precursor cell type from bovine subcutaneous white adipose tissue. J. develop. Physiol., 2 , 275-289.

PLANCHE E., BOULANGÉ A., de GASQUET P., TONNU N. T., 1980. Importance of muscle lipoprotein lipase in rats during suckling. Am. J. Physiol., 238, E511-E517.

POSSMAYER F., 1982. The perinatal lung, 337-391. In JONES C. T., Biochemical development of the fetus and neonate, Elsevier biomed. Press, Amsterdam. 
PYKALISTO O. J., SMITH P. J., BRUNZELL J. D., 1975. Determinants of human adipose tissue lipoprotein lipase. J. clin. Invest., 56, 1108-1117.

QUINN D., SHIRAI K., JACKSON R. L., 1982. Lipoprotein lipase : mechanism of action and role in lipoprotein metabolism. Prog. Lipid Res., 22, 35-78.

RATH E. A., HEMS D. A., BELOFF-CHAIN A., 1974. Lipoprotein lipase activities in tissues of normal and genetically obese (ob/ob) mice. Diabetologia, 10, 261-265.

REICHL D., 1972. Lipoprotein lipase activity in the adipose tissue of rats adapted to controlled feeding schedules. Biochem. J., 128, 79-87.

ROBINSON D. S., 1970. The function of the plasma triglycerides in fatty acid transport. Comp. Biochem., 18, 51-116.

RODBELL M., 1964. Localization of lipoprotein lipase in fat cells of rat adipose tissue. J. biol. Chem., 239, 733-755.

RODOMSKI M. W., ORME T., 1971. Response of lipoprotein lipase in various tissues to cold exposure. Am. J. Physiol., 220, 1852-1859.

RONCARI D. A. K., VAN R. L. R., 1978. Adipose tissue cellularity and obesity : New Perspectives. Clin. Invest. Med., 1, 71-79.

ROKOS J., HAHN P., KOLDOVSKY O., PROCHAZKA P., 1963. The post-natal development of lipolytic activity in the pancreas and small intestine of the rat. Physiol. Bohemoslov., 12, 213219.

ROTHWELL J. E., ELPHICK M. C., 1982. Lipoprotein lipase activity in human and guinea-pig placenta. J. develop. Physiol., 4, 153-160.

SCHENK H., HEIM T., MENDE T., VARGA F., GOETZE E., 1975. Studies in plasma free-fatty-acid metabolism and triglyceride synthesis of brown adipose tissue in vivo during cold induced thermogenesis in the newborn rabbit. Eur. J. Biochem., 58, 15-22.

SHRAGO E., SPENNETTA T., GORDON E., 1969. Fatty acid synthesis in human adipose tissue. J. biol. Chem., 244, 2761-2766.

SCHRIEBLER T. H., WOLFF H. H., 1966. Electronmicroskopische Untersuchunsen am Herzmuskel der Ratte wahrend der Entwicklung. Z. Zellforsch., 69, 22-44.

SCOW R. O., BLANCHETTE-MACKIE E. J., SMITH L. C., 1976. Role of capillary endothelium in the clearance of chylomicrons. A model for lipid transport from blood by lateral diffusion in cell membranes. Circ. Res., 39, 149-162.

SHEMESH M., BENSADOUN A., HANSEL N., 1976. Lipoprotein lipase activity in the bovine corpus luteum during the oestrus cycle and early pregnancy. Proc. Soc. exp. Biol. Med., 151, 667669.

SHIMADA K., GILL P. J., SIBERT J. E., DOUGLAS W. H., FAUBURG B. L., 1981. Involvement of cell surface heparan sulfate in the binding of lipoprotein lipase to cultured bovine endothelial cells. J. clin. Invest., 68, 995-1002.

SIMPSON J., 1979. Rapid effects of isoprenaline, glucagon, pacing and potassium arrest on postheparin lipoprotein lipase activity in the perfused rat heart. Biochem. J., 182, 253-255.

SMITH L. C., SCOW R. O., 1979. Chylomicrons Mechanism of transfer of Lipolytic products to cells. Prog. biochem. Pharmacol., 15, 109-138.

SPENCER I. M., HUTCHINSON A., ROBINSON D. S., 1978. The effect of nutritional state on the lipoprotein lipase activity of isolated fat cells. Biochim. biophys. Acta, 530, 375-384.

STEFFEN D. G., BROWN L. J., MERSMANN H. H., 1978. Ontogenic development of swine (Sus domesticus) adipose tissue lipases. Comp. Biochem. Physiol., 59B, 195-198.

TAN M. H., SATA T., HAVEL R. J., 1977. The significance of lipoprotein lipase in rat skeletal muscles. J. Lipid Res., 18, 363-370.

TORSTI P., 1965. Thyroxine and the heart lipoprotein lipase. Ann. Med. exp. fenn., 43, 245-247.

TRAYHURN P., 1981. Fatty acid synthesis in brown adipose tissue. The influence of environmental temperature on the proportion of whole body fatty acid synthesis in brown adipose tissue and liver. Biochim. biophys. Acta., 664, 549-560.

VAN R. L. R., RONCARI D. A. K., 1978. Complete differentiation of adipocyte precursors. A culture system for studying the cellular nature of adipose tissue. Cell Tiss. Res., 195, 317323.

VANHOVE A., WOLF C., BRETON M., GLANGEAUD M.-C., 1978. Effects of nutrition on subcellular localization of rat fat cell lipoprotein lipase. Biochem. J., 172, 239-245. 
VANNIER C., HANSEN H., FOREST C., AILHAUD G., NÉGREL R., 1982. Induction and localization of lipoprotein lipase during the adipose conversion of ob 17 cells. In The adipocyte and obesity : cellular and molecular mechanisms. Proc. int. Conf., Toronto, Canada, p. 7.

VERINE A., SALERS P., BOYER J., 1982. Effects of apolipoproteins C on lipoprotein lipase activity bound to rat fat cells. Am. J. Physiol., 243, E175-E181.

VERNON R. G., CLEGG R. A., 1984. The metabolism of white adipose tissue in vivo and in vitro. In CRYER A., VAN R. L. R., New perspectives in adipose tissue structure, function and development. Butterworths, London (in the press).

VYDELINGUM N., DRAKE R. L., ETIENNE J., KISSEBAH A. H., 1983. Insulin regulations of fat cell ribosomes, protein synthesis, and lipoprotein lipase. Am. J. Physiol., 245, E121-E131.

WEINHOLD P. A., QUADE M. M., BROZOWSKI T. B., FELDMAN D. A., 1980 . Increased synthesis of phosphatidylcholine by rat lung following premature birth. Biochim. biophys. Acta, 617, 76-84.

WEISSEMBURG-DELORME C. L., HARRIS K. L., 1975. Effects of diet on lipoprotein lipase activity in the rat. J. Nutr., 105, 447-451.

WILLIAMS M. P., STREETER H. B., WUSTEMAN F. S., CRYER A., 1983. Heparan sulphate and the binding of lipoprotein lipase to porcine thoracic aorta endothelium. Biochim. biophys. Acta, 756, 83-91.

WILSON D. E., FLOWERS C. M., CARLILE S. J., UDALL K. S., 1976. Estrogen treatment and gonadal function in the regulation of lipoprotein lipase. Atherosclerosis, 24, 481-499.

ZINDER O., HAMOSH M., CLARY-FLECK T. R., SCOW R. O., 1984. Effect of prolactin on lipoprotein lipase in mammary gland and adipose tissue of rat. Am. J. Physiol., 226, 744-748 